DOI:10.22337/2587-9618-2020-16-1-73-85

\title{
TO ASSESS THE HORIZONTAL DISPLACEMENT OF PILES CAUSED BY EXCAVATION OF THE SOIL OF THE PIT
}

\author{
D.S. Kolesnik, Rashid A. Mangushev \\ Saint-Petersburg State University of Architecture and Civil Engineering, Saint-Petersburg, RUSSIA
}

\begin{abstract}
The article discusses and justifies the cases of horizontal movement of the top of the piles in the case of digging a pit of great depth. A statistical analysis of the results of executive documentation for completed pile fields at three construction sites in St. Petersburg was carried out, which made it possible to prove the causes of excess movements of the pile heads. A technique for assessing deformations depending on the depth of excavation of the pit and the characteristics of the soil base is proposed. The decrease in the modulus of subgrade reaction for calculating piles in the conditions of softened soils near the pile space is proved.
\end{abstract}

Keywords: piles, horizontal loading, excavation of the pit, deflection of the heads of piles, soft clay soils.

\section{К ОЦЕНКИ ГОРИЗОНТАЛЬНОГО СМЕЩЕНИЯ СВАЙ ВЫЗВАННОГО ЭКСКАВАЦИЕЙ ГРУНТА КОТЛОВАНА}

\author{
Д.С. Колесник, Р.А. Мангушев \\ Санкт-Петербургский государственный архитектурно-строительный университет, \\ г. Санкт-Петербург, РОССИЯ
}

\begin{abstract}
Аннотация: В статье рассматриваются и обосновываются случаи горизонтального перемещения верха свай в случае рытья котлована значительной глубины. Был проведен статистический анализ результатов исполнительной документации по заполненным свайным полям на трех строительных площадках в СанктПетербурге, что позволило доказать причины избыточных перемещений свайных головок. Предложена методика оценки деформаций в зависимости от глубины выемки котлована и характеристик грунтового основания. Доказано уменьшение модуля реакции субстрата для расчета свай в условиях размягченных почв вблизи свайного пространства.
\end{abstract}

Ключевые слова: сваи, горизонтальная загрузка, выемка котлована, прогибы свай, мягкие глинистые почвы

\section{INTRODUCTION}

In modern civil engineering, the organization of underground volumes is increasingly used with the placement of parking lots, used cellars, communications, etc.

In the conditions of the spread of large strata of weak clay soils, the arrangement of underground premises is fraught with difficulties and risks associated with the construction of a foundation pit fence. The most rational construction of the foundation in this case are piles made from the upper surface before the excavation.
The spread of pile foundations is associated, among other things, with a reduction in the duration of the zero-cycle work compared to footings on a natural foundation. The speed of the work is achieved due to the high technical characteristics of the equipment, as well as the combination of the processes of performing elements of the pile field and excavation of the pit.

As a rule, for the rational use of the underground space, a pit is usually performed with a depth of 5 to $8 \mathrm{~m}$, with one or two basement floors, respectively. The installation of piles for buildings with an underground volume is usually 
performed from the upper surface with the subsequent development of the pit to the design level. A driven or pressed-in pile can be put down with a mark of its head below the soil surface by $3-5 \mathrm{~m}$, respectively, when using equipment for additional pressure to pile.

The mark of the top of piles made by drilling or ramming technology is usually combined with the horizon from which work is performed. The pile shaft above the assumed grillage is made unreinforced using the same concrete as the main section for piles of small diameter (up to 520 $\mathrm{mm}$ ) or made of sand for larger piles, when it is economically viable.

Note that when performing elements of a pile field from the bottom of the pit, additional costs arise for the arrangement of ramps or the operation of cranes necessary to deliver construction equipment to the front of the work. In addition, in order to be able to carry out extreme piles, it is necessary to increase the dimensions of the pit compared to the first option. These measures are usually not economically feasible, and sometimes impossible if there is an existing dense building on the building site.

The excavation of foundation pits of basements in the conditions of the spread of soft soils is carried out after the organization the fencing under the protection of spacers or soil berm [1]. Excavation pits, spacer structures and soil berms are calculated according to their strength and stability to ensure mechanical safety of both the new construction project itself and the surrounding buildings. These calculations are performed on the condition that the permissible additional settlement of neighboring buildings is not exceeded.

On the other hand, maps of soils excavation and transport patterns during the excavation are reflected in the project of construction organization (PCO).

The sections of the documentation related to PCO do not suggest the possibility of serious errors or omissions in them, which, in turn, can lead to accidents or additional costs. These documents are developed from the experience of construction and production facilities of the contractor. It is assumed that all the necessary analytical calculations and, especially, modeling in the FEM programs are carried out in the design of load-bearing and enclosing structures. In addition, a design organization is assigned a technique for performing pile field and loading on the of the pit boundaries.

Standard GOST 27751-2014 [2] prescribes to consider design transitional situations, that is, situations that have a short duration compared to the service life of a construction object. In particular, piles already completed, on which any external influence is exerted, must be calculated on it from the condition of limiting displacement, deflections, and moments. An example of such impacts is - loads on the soil caused by the operation of pile equipment, loads from moving or storing goods in the immediate vicinity of the pile or, loads caused by excavation of the pit.

When excavating a pit, the difference in elevations (from the layout to the bottom of the pit) causes horizontal pressures acting on the piles. If this factor is not taken into account, then at a significant pit depth (of the order of $5 \mathrm{~m}$ ) in conditions of weak underlying soils, the pile heads receive significant deviations, reaching the order of several of their diameters and often exceeding the permissible ones (Figure 1).

As it is known, grillages are designed so that their contours overlap the contour of the pile field by $0.2 \mathrm{~d}$, where $d$ is the diameter or width of the pile. If the position of the goals in the plan exceeds these admissions, then we have to change the construction of the foundations, which entails the loss of time and material resources. In a number of cases, the question arises about the possibility of incorporating deviated piles into the work or their duplication.

Almost all federal or regional technical documents on the organization of work do not consider this aspect. An exception is one of the organization's standards [3], which limits the depth of cut during excavation by two meters, but this standard is based on practical experience in the manufacture of indentation piles in St. Petersburg, which of course cannot be extended to all possible cases. 


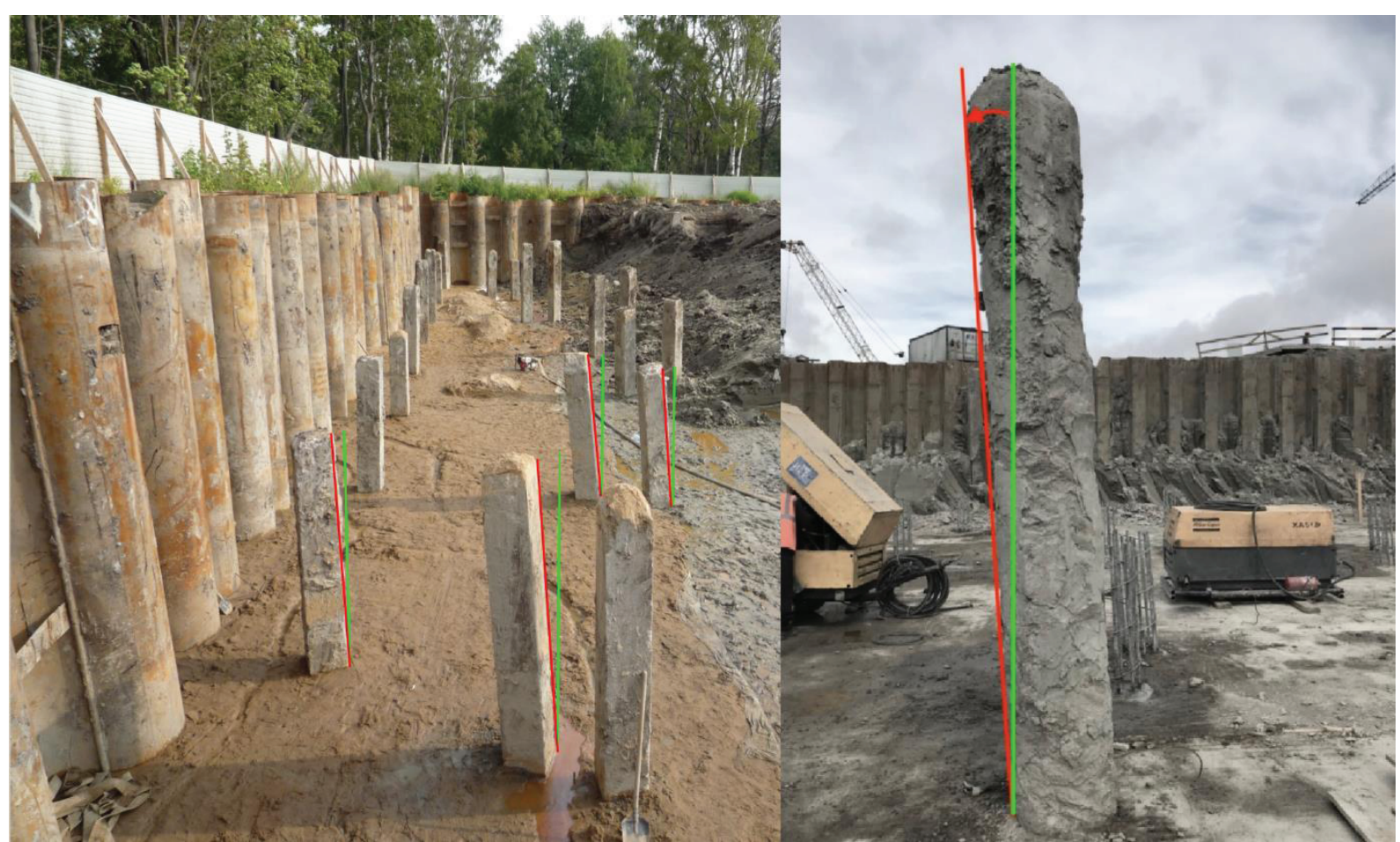

Figure 1. Horizontal displacements of driven and bored piles.

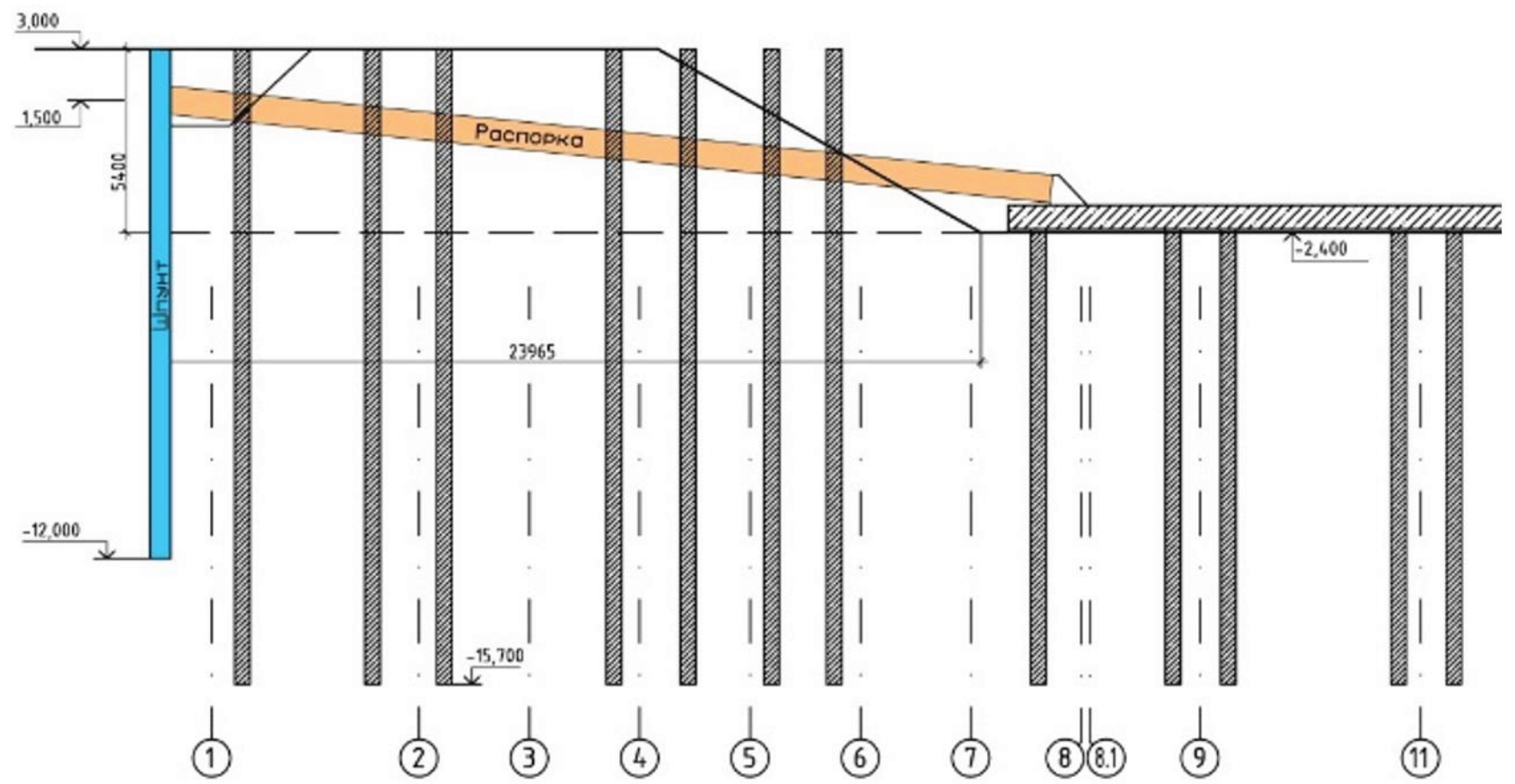

Figure 2. General scheme of the structural elements of the pit, spacer system, pile foundation.

On the other hand, forecasting and calculating such situations does not fall into the area of responsibility of specialized organizations, even if they carried out a geotechnical substantiation or design of enclosing structures. Relatively simple modeling of excavation in a two- dimensional setting (a series of piles is presented in the form of a wall) gives underestimated values of forces in structures [4]. Thus, in the general case, highly qualified engineers and special software are required that allow threedimensional modeling of the soil range $[5,6]$. 


\section{EXAMPLES AND ANALYSIS} OF THE HORIZONTAL DEVIATION OF THE UPPER PART OF THE PILES DURING THE EXCAVATION OF PITS

As an example of horizontal deviation of piles, we can consider the construction of a parking lot for a residential building under construction in one of the districts of St. Petersburg.

The foundation of the car park of one of the buildings is a grillage slab resting on a pile field of 216 bored piles with a diameter of $d=520 \mathrm{~mm}$ and a length of $\mathrm{L}=14.3 \mathrm{~m}$ (after felling) made using the Fundex technology $[7,8]$. The point of the piles is entered into moraine glacial deposits lgIII, represented by dusty sandy loam and loam with gravel and pebbles). The calculated load on the pile adopted $\mathrm{N}=1500 \mathrm{kN}$.
The arrangement of the underground space involved the excavation of a pit to a depth of 5.4 $\mathrm{m}$. At the first stage of excavation of the pit, soil was extracted to the design level of the bottom of the pit with the arrangement of soil berm. On the following, a grillage slab and a strut system were carried out, after which the final excavation of the soil from the pit was carried out. Figure 2 shows a general diagram of the pit indicating the marks of structural elements of the fence, piles, grillage slabs.

Because of the first stage of work, previously manufactured piles received significant deviations in plan. As can be seen from Figure 3, measured in the process of geotechnical monitoring, the displacement of elements in a pile field is characterized by large values as they approach the pit edge (soil berm).

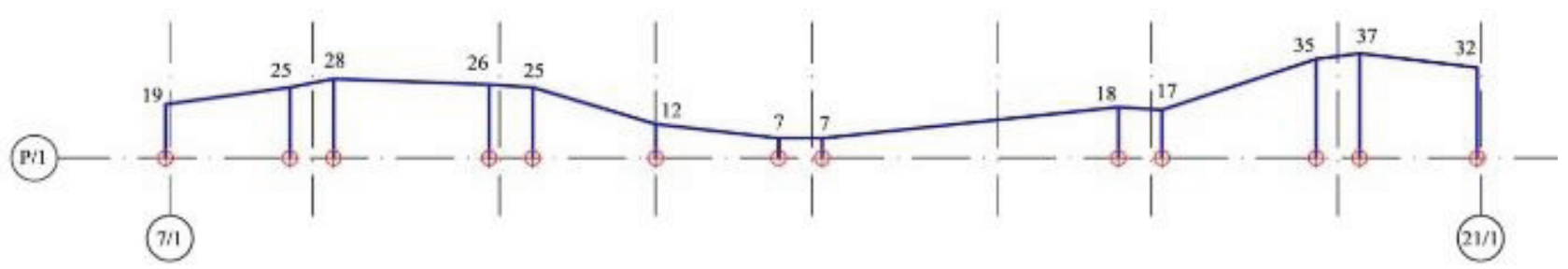

Figure 3. Diagram of the horizontal displacement of piles in $\mathrm{cm}$ (section along the P / 1 axis).

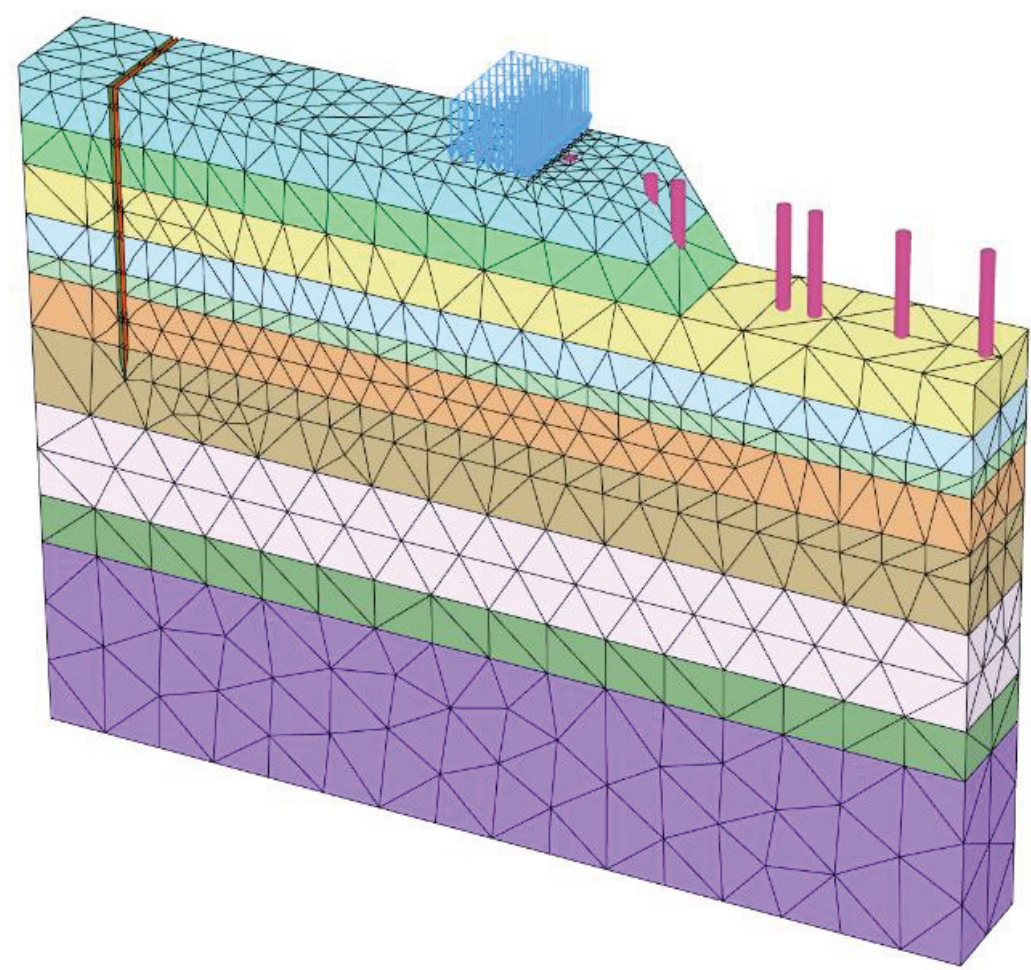

Figure 4. The design scheme of the simulated area. 
The displacement of the heads of piles is associated with the horizontal pressure of the soil during the complete excavation of the excavation soil. The indicated effect is obvious from the point of view of soil mechanics and is confirmed by numerical calculation in the Plaxis $3 \mathrm{D}$ software package (Fig. 4). The simulation results showed that the deviation of the top of the piles can reach $46 \mathrm{~cm}$ or more. The horizontal movement of piles at an absolute mark of 1.780 (felling) reaches $25 \mathrm{~cm}$.

Figures 4 and 5 show a design diagram including a series of piles along the "P / 1" axis and a soil mass limited by the " 1 " and " $14 / 1$ " axes. On the edge of the slope, the load distributed over the area is simulated by pressure from the excavator. The calculation was carried out in several stages of soil excavation in the direction from the center of the pit (axis "14/1") to the sheet pile fence (axis "1"). Figure 6 shows plots of horizontal movements of piles during excavation of the central part of the pit in the axes "7" - "22" with the arrangement of soil berms. The implementation of such calculations for labor costs is comparable to the design of the capital construction objects themselves. Thus, for the described design case (a combination of weak clay soils and a large excavation depth), the need for expanding the set of design documentation with the geotechnical substantiation section related to the work below zero is obvious.

\section{STATISTICAL ANALYSIS OF HORIZONTAL DEVIATIONS OF THE TOP OF THE PILES DURING THE CONSTRUCTION OF PITS}

The situation when during the excavation of the pit piles get bent and horizontal movement is relatively new and is little reflected in both technical documents and scientific publications. There is no justification of the necessary time from the moment of completion of piles to their excavation, which would allow the restoration of structural bonds in the soil near the pile space. For this case, the load on the edge of the excavation pit, for example, from a pile-pressing installation, the weight of which can reach up to $1200-1600 \mathrm{kN}$, is also not taken into account.

As is known, Russian Building Code SP 45.13330.2017 [9] limits the horizontal movement of the heads at the tape and cluster piles to $0.2 \mathrm{~d}$ ( $0.3 \mathrm{~d}$ for deviations along the row). Obviously, these deviations take into account the geodetic error and production technology errors, but not horizontal movements of piles caused by excavation of the pit [10].

Based on the results of the consideration of technical as-built documentation for the completed work of the zero cycle, the materials were analyzed when installing pile foundations at sites with similar geological conditions at three sites in St. Petersburg. On all construction sites, factory-made piles were used, made before excavating the pit.

During statistical processing, a section with the number of piles of more than 150 pieces was selected (for object No. 2, two grips were selected that differ in the way the piles were grouped).

For all objects, the characteristic depth of excavation was 4.2 - $4.6 \mathrm{~m}$. Clay soils underlying the bottom of the pit belonged to a fluid or fluid plastic consistency. The thickness of the underlying layer is comparable to the length of piles and amounted to $11-20 \mathrm{~m}$.

Figure 7 shows the distribution of the number of piles with one or another deviation of the heads. The main characteristics of the considered objects are given in Table. 1. 
D.S. Kolesnik, Rashid A. Mangushev

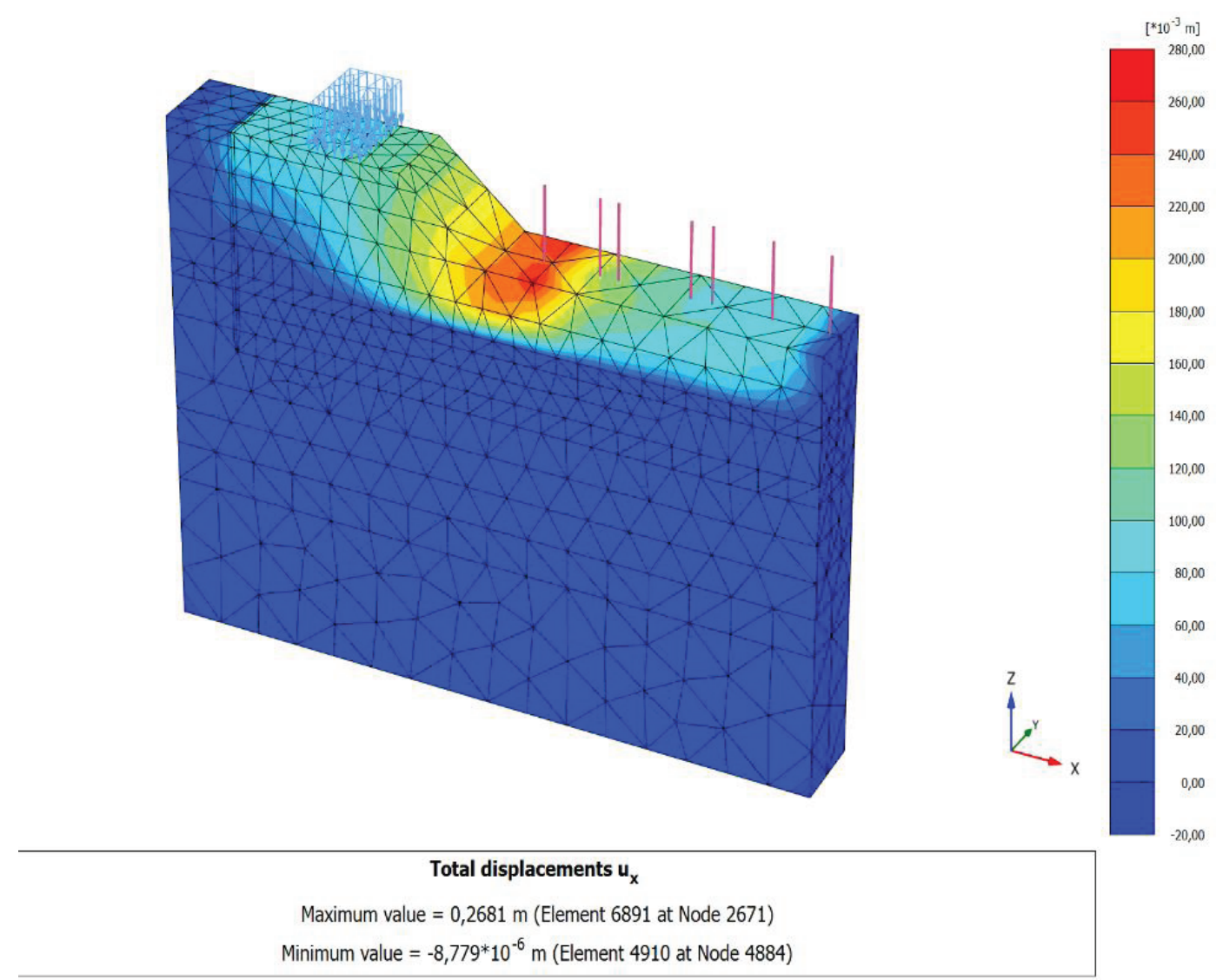

Figure 5. Horizontal movements of the soil mass during excavation.
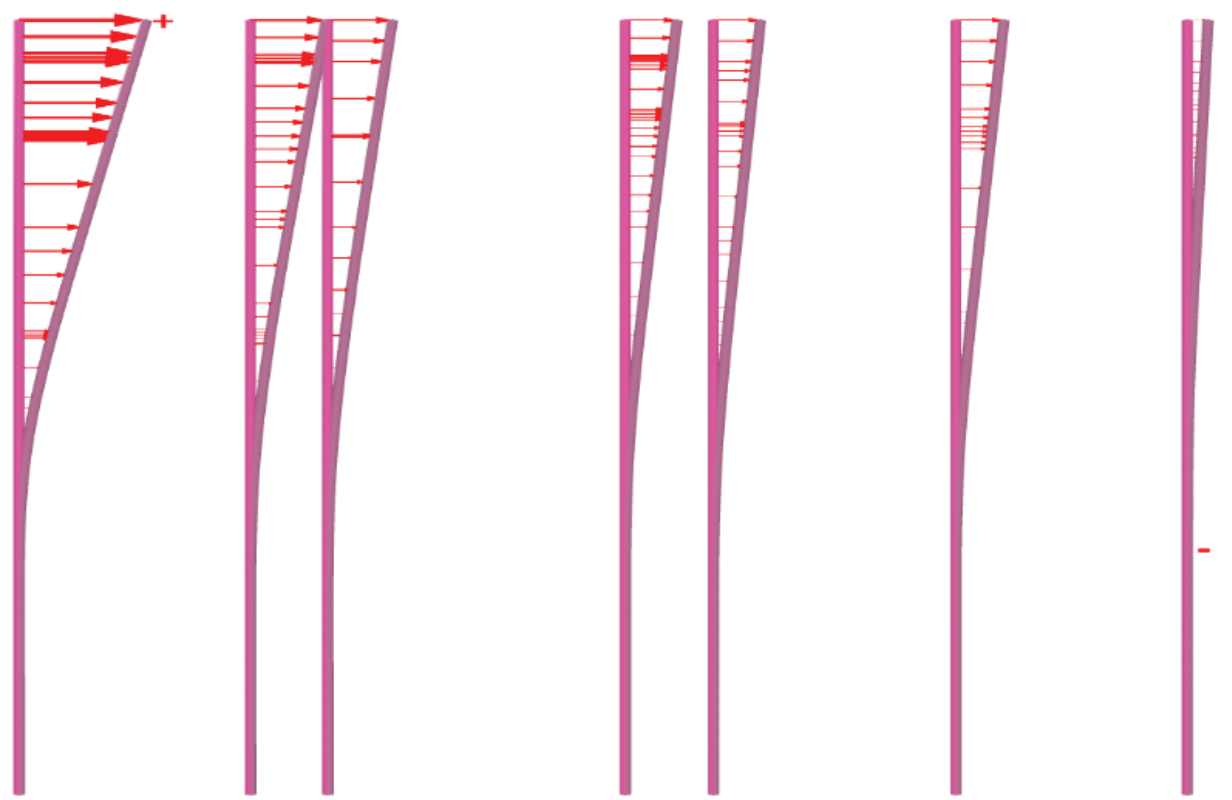

Total displacements $\mathbf{u}_{\mathbf{x}}$ (scaled up 5,00 times)

Maximum value $=0,4633 \mathrm{~m}$ (Element 213 at Node 13297)

Minimum value $=0,02096 * 10^{-3} \mathrm{~m}$ (Element 28 at Node 12923)

Figure 6. The calculated horizontal movements of piles during excavation of the central part of the pit with the device of soil berms. 


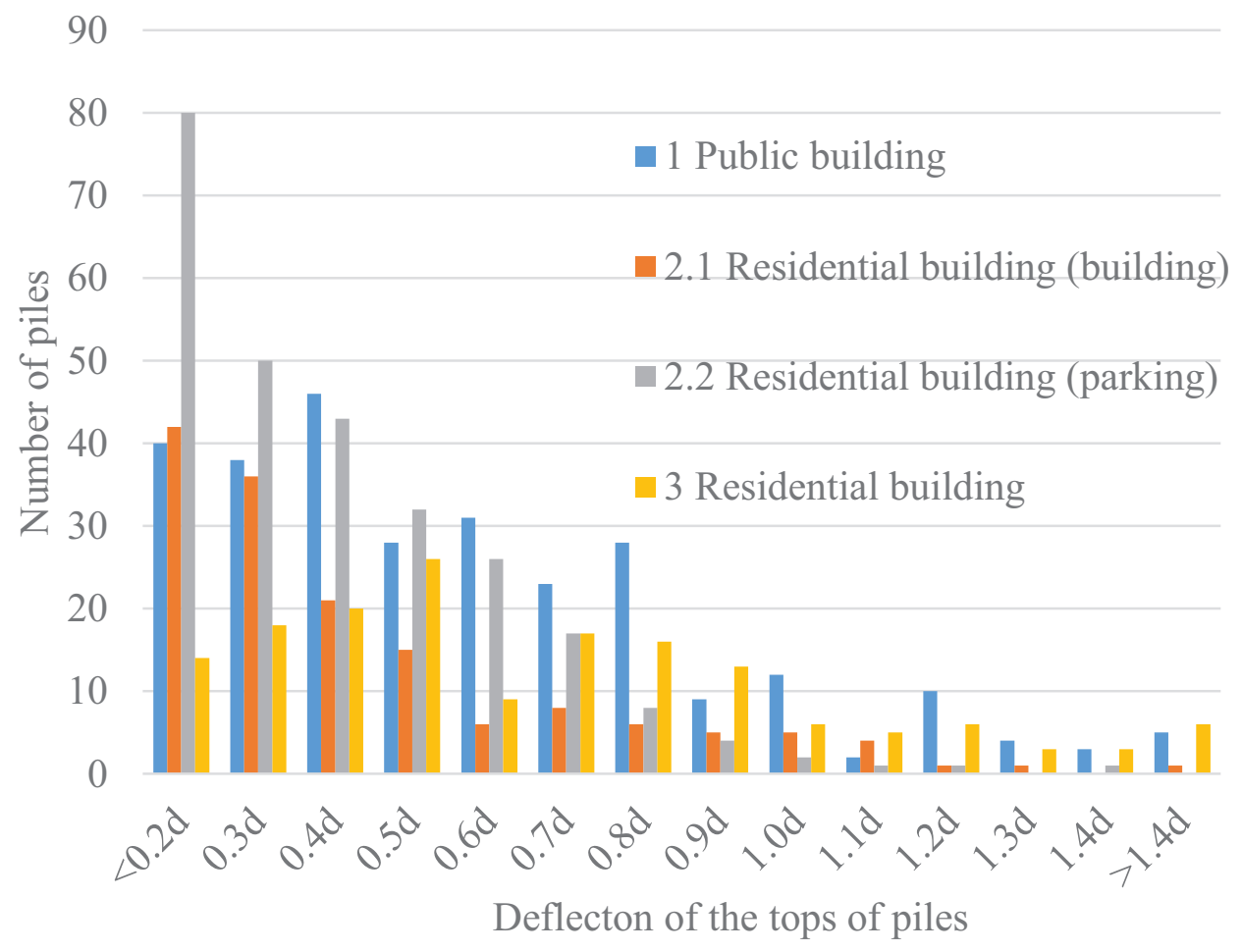

Figure 7. The distribution of the number of piles according to the deviation from the vertical.

Note that the values of deviations of piles after excavation is quite random. Basically, there is a deviation towards the excavation of the pit. On the other hand, the possibility of "accidental" movement, for example, across the slope or to each other for two adjacent piles, is not ruled out. Such their behavior can be caused by: excavation of neighboring elements from different sides, random loads along the edge of the pit, or piles being under load for a long time (during a break in work). In fig. 8 as an example, the value of the deviations of piles in the direction of excavation is presented, which amounted to: $1825 \mathrm{~cm}$ (0.45d-0.6d), across: $1-3 \mathrm{~cm}$, which fits into the permissible error. Lines from the center of the piles indicate the movement of their head. At the same time, the maximum movements of piles reached $79 \mathrm{~cm}$. As can be seen from the analysis of Figures 7, 8 and Table 1, in some cases, when digging pits of great depth in weak soils, horizontal deviations of the pile heads are observed, significantly exceeding the permissible values adopted in SP 45.13330.2017
[9], which in some cases required changes to the design of the pile field. Obviously, such movements should be predicted and appropriate amendments made in the design decisions of the zero cycle.

\section{METHODOLOGY FOR ASSESSING THE DEVIATION OF PILES DURING EXCAVATION OF THE PIT}

The method of calculating piles for horizontal loads was first formulated in the 1930s by Professor Urban [11], as a solution to a boundary problem. After 40 years, on the basis of field tests, the most generalized theory was developed, which was included in regulatory documents [12]. The main principles of the calculation are to consider the pile as a beam located on an elastic Winkler base, characterized by increasing depth of rigidity; force and moment are applied to one end of the beam, the other, in turn, has a fastening, depending on the soil. 


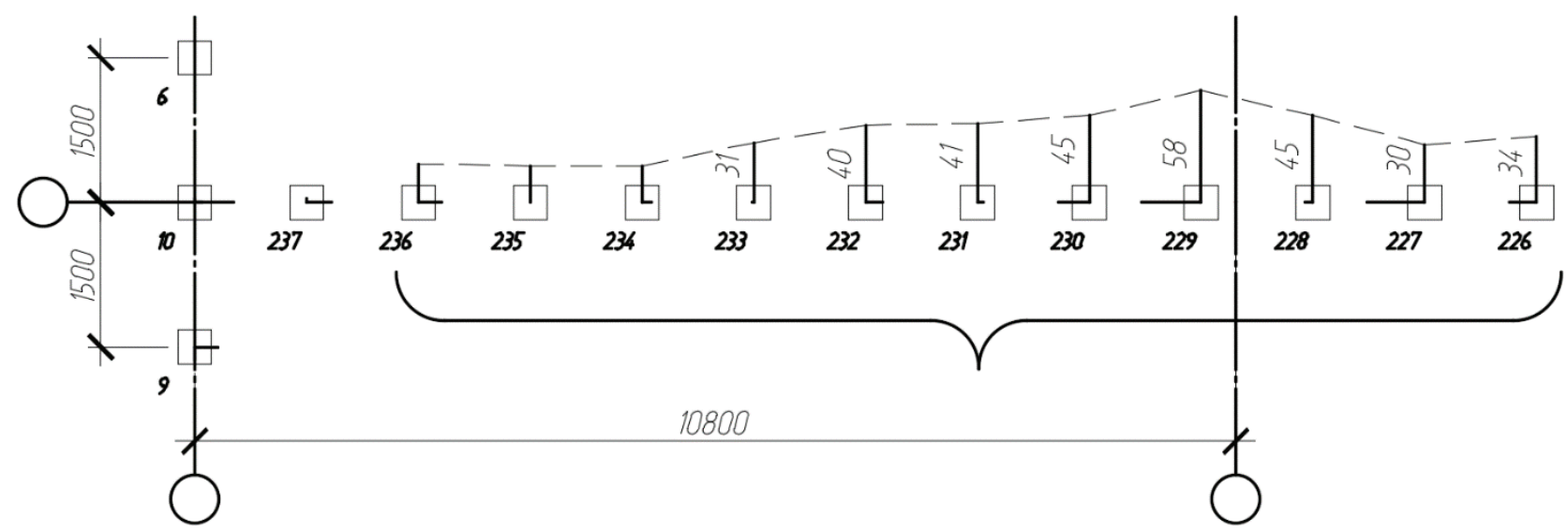

Figure 8. Fragment of the executive scheme of the pile field (object 1).

At present, instead of solving the laborious boundary value problem [13], displacement and force in piles can be determined by the finite element method [14] in a one-dimensional formulation. The described technique can be generalized to the case of a distributed load applied to a pile, since this does not contradict the formal logic.

We find linear loads on the pile from the solution of the Flaman problem [15]. This solution allows us to determine the horizontal stresses in the elastic half-space of the soil from an infinite band load applied to its face. The moment of excavation of a pile (Figure 4) located approximately at a distance of $1 / 3$ of the length of the slope is considered, counting from its beginning. Soil located above the pile head is divided into elementary strips of width $b 0$ $(0.2 \mathrm{~m})$. The slope angle is taken equal to 45 degrees. The expression for determining the stresses in the plane of the pile face is presented in the form:

$$
\sigma_{y}=\sum_{i=1}^{n} \frac{2 \gamma h_{i} b_{0}}{\pi} * \frac{|x| * x * z}{\left(x^{2}+z^{2}\right)^{2}}
$$

where $\sigma_{\mathrm{y}}$ is horizontal stress at the desired point, $\mathrm{kPa} ; i$-element band number; $n$ - the number of elementary strips ( 60 pcs.); $\gamma$ - specific gravity of soil, $\mathrm{kN} / \mathrm{m} 3 ; h_{i}$ - elementary strip height; $b_{0}$ width of the elementary strip, $\mathrm{m} ; x$ - distance from the considered point to the elementary strip, $\mathrm{m} ; z$-depth, $\mathrm{m}$.
As you know, the basis of the Winkler model is customary to describe through the modulus of subgrade reaction, which depends on the depth and type of soil. It was experimentally established [16] that this modulus in clay soils increases linearly with depth. To maintain generality, we use the normative formula [14]:

$$
c_{z}=\frac{K z}{\gamma_{c}}
$$

where $c_{z}$ - the estimated value of the coefficient of bed soil, $\mathrm{kN} / \mathrm{m} 3 ; K$ - coefficient of proportionality depending on the type of soil, $\mathrm{kN}$ $/ \mathrm{m} 4 ; z$ - depth at which the section is located, $\mathrm{m}$; $\gamma_{c}-$ coefficient of working conditions (for a separate pile $\gamma \mathrm{c}=3$ ).

The problem with this approach to assessing the movements of piles during their excavation is the difficulty of assigning a proportionality coefficient $(\mathrm{K})$ for fluid clay and thixotropic soils. It is also obvious that the safety factor $\gamma \mathrm{c}$ does not take into account the softening of the near-pile soil that occurs during its unloading and the introduction of piles [17]. We rewrite the formula as follows:

$$
c_{z}=\frac{K z}{\alpha \gamma_{c}}
$$

where $\alpha$ is correction coefficient.

The basic calculation schemes for the example of object No. 1 are shown in Figure 5. 


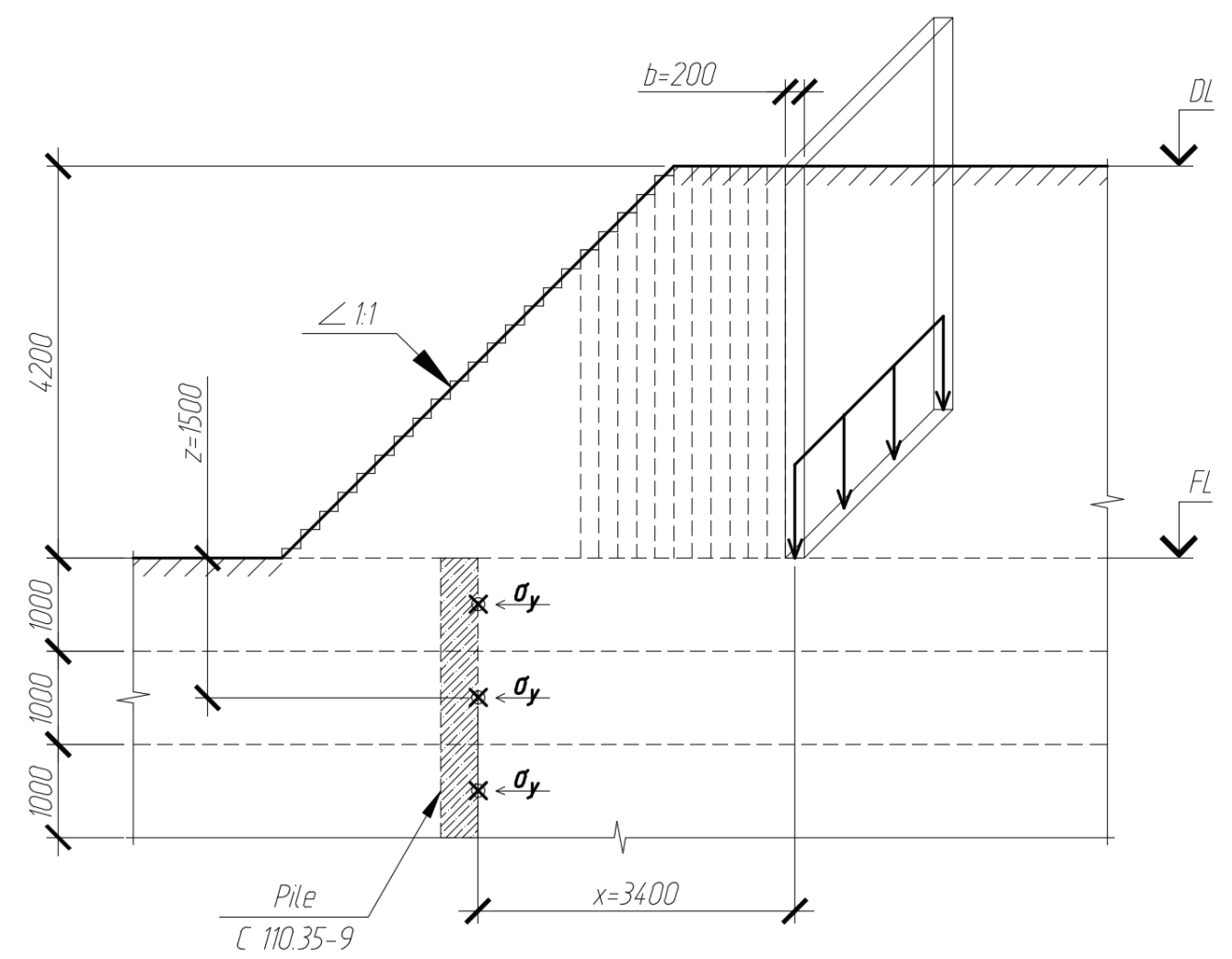

Figure 9. Scheme for determining horizontal stresses (object 1).

The proportionality coefficient $\mathrm{K}$ was taken equal to $4000 \mathrm{kN} / \mathrm{m} 4$, the safety factor $\gamma$ with equal to three, as for a single pile.

The conditional pile width for computer calculation is taken to be equal to the physical pile width $\mathrm{d}$, and not $1.5 \mathrm{~d}+0.5 \mathrm{~m}$, as is required in [14]. This conditional pile width is introduced into the calculation to take into account the influence of the size of the cross section of the pile on the soil resistance of the undisturbed structure [12]. It is likely that the soil in the nearpile zone will have large displacements along the slope, in comparison with the soil on which the pile "lies" and will not impede the movement of the pile.

The calculation of tasks for each object using the finite element method was carried out in LIRA SAPR 2015 software. The coefficient $\alpha$ was selected so that the resulting displacement of the column head coincided with the median value of deviations for the object. The results are summarized in Table 1.

The value of the correction coefficient $\alpha$ was 17 34 , which corresponds to the movement of the pile head by $17-24 \mathrm{~cm}$ under the given ground conditions. Thus, the value of the normative coefficient of bed decreases by several tens of times, which is associated with a violation of structural bonds in the soil during the execution and excavation of piles.

For the most problematic elements of the pile field, non-destructive continuity control was performed by the seismic-acoustic method. The calculated moment exceeded the moment of crack formation by $10-20 \%$ (Table 1), at depths corresponding to the jump of the reflectogram (510 diameters of piles).

It should be noted that the normative safety factor $(\gamma c)$ is taken to be equal to three only when calculating mono-pile foundations (support of lampposts, etc.). On the other hand, in the practice of domestic and foreign construction, there are cases of sliding piles into the foundation pit, united by grillage [4]. Thus, in these design cases, it is necessary to take the safety factor the same as when calculating a single pile. 


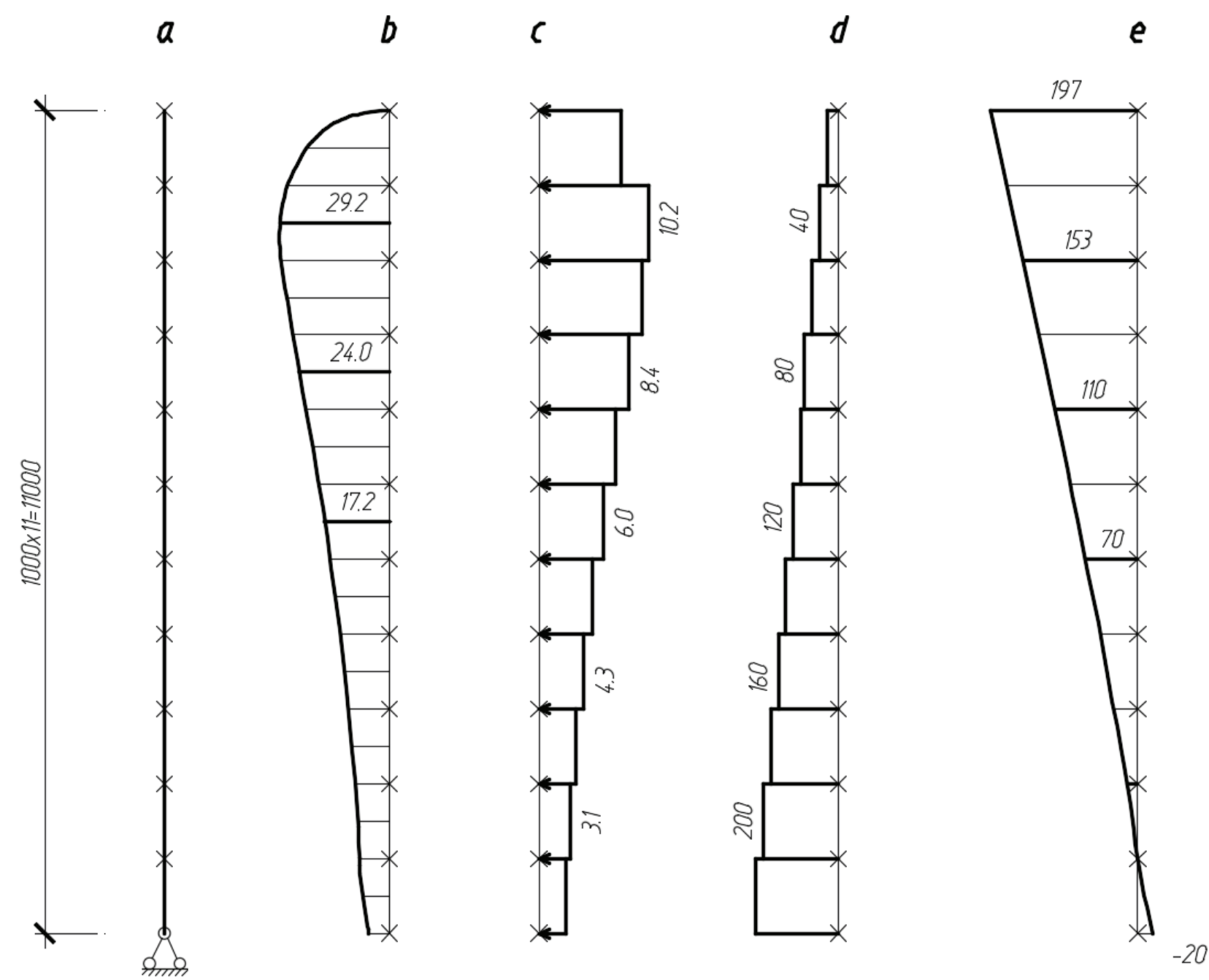

Figure 10. a) the geometric pattern of the pile; b) plot of stresses in the ground, $\mathrm{kPa}$; c) linear loads on the beam, $\mathrm{kN} / \mathrm{m}$; d) the values of the coefficients of the bed of soil, $\mathrm{kN} / \mathrm{m} 3$; e) resulting horizontal movement of the pile, $\mathrm{mm}$ (object 1).

Based on the construction experience and the provisions set forth in this article, the following conclusions can be drawn:

1. Obviously, the displacement of the heads of piles is associated with horizontal pressure and the movement of the soil of the slopes during the excavation of the pit.

2. The greatest influence on the deviation of the pile heads is exerted by the excavation depth of the pit and the presence of weak soils at the base.

3. To reduce the impact from the berms and slopes of the pit and to minimize the horizontal deviation of the completed piles, excavation should be carried out by excavations with the initial excavation of the pile field and the further development of the soil berm

4. In some cases, excavation of the pit should be carried out with captures of small depth (of the order of $1 \mathrm{~m}$ ), so that the piles receive deviations in the other direction than at the previous stage of work.

5. It is necessary to assign a break between the implementation of piles and excavation of the soil during the excavation of the pit to restore its properties 
To Assess the Horizontal Displacement of Piles Caused by Excavation of the Soil of the Pit

Table 1. The main characteristics of the considered objects.

\begin{tabular}{|c|c|c|c|c|}
\hline Number of object & $\begin{array}{c}1 \\
\text { Public building }\end{array}$ & $\begin{array}{c}2.1 \\
\text { Residential } \\
\text { building } \\
\text { (building) } \\
\end{array}$ & $\begin{array}{c}2.2 \\
\text { Residential } \\
\text { building } \\
\text { (parking) } \\
\end{array}$ & $\begin{array}{c}3 \\
\text { Residential } \\
\text { building }\end{array}$ \\
\hline A type of the pile & C 110.35-9 & C $160.40-10$ & C $150.40-10$ & С 200.40-НСв.6 \\
\hline $\begin{array}{c}\text { Absolute excavation } \\
\text { mark, } \\
\text { m }\end{array}$ & $-4,200$ & $-4,600$ & $-4,600$ & $-4,300$ \\
\hline Recoverable soil & Dusty Sands & \multicolumn{2}{|c|}{ Bulk Peat } & Bulk \\
\hline Underlying soil & $\begin{array}{l}\text { Loamy, dusty, } \\
\text { light loams }\end{array}$ & \multicolumn{2}{|c|}{ Loamy, fluid-plastic loams } & $\begin{array}{l}\text { Plastic sandy } \\
\text { loam, with } \\
\text { flowing streaks, } \\
\text { thixotropic }\end{array}$ \\
\hline $\begin{array}{l}\text { Characteristics } \\
\text { of the underlying soil }\end{array}$ & $\begin{array}{c}\mathrm{I}_{\mathrm{L}}=1.05 . .1 .3 \\
\mathrm{E}=6 . .3 \mathrm{M \Pi a} \\
\mathrm{h}=9.8 \mathrm{M}\end{array}$ & \multicolumn{2}{|c|}{$\begin{array}{l}\mathrm{I}_{\mathrm{L}}=0.91 . .1 .21 \\
\mathrm{E}=5.5 . .8 \mathrm{MПа} \\
\mathrm{h}=10.8 \mathrm{M}\end{array}$} & $\begin{array}{c}\mathrm{I}_{\mathrm{L}}=0.93 \\
\mathrm{E}=9 \mathrm{M \Pi a} \\
\mathrm{h}=12.1 \mathrm{M}\end{array}$ \\
\hline Technologies & Indentation & Indentation & Indentation & Driving \\
\hline Type of grillages & band & band & field & band \\
\hline $\begin{array}{l}\text { Pile pitch in grillage, } \\
\mathrm{mm}\end{array}$ & 1200 & 1200 & 1200 & 1200 \\
\hline $\begin{array}{l}\text { Number of piles per } \\
\text { grip }\end{array}$ & 279 & 151 & 264 & 162 \\
\hline $\begin{array}{l}\text { The number of piles } \\
\text { with a deviation of } \\
\text { more than } 0.2 \mathrm{~d} \\
(\% \text { of the total })\end{array}$ & $\begin{array}{c}239 \\
(86 \%)\end{array}$ & $\begin{array}{c}109 \\
(72 \%)\end{array}$ & $\begin{array}{c}185 \\
(70 \%)\end{array}$ & $\begin{array}{c}148 \\
(91 \%)\end{array}$ \\
\hline $\begin{array}{c}\text { The number of piles in } \\
\text { the sample } \\
\text { (\% of the total) }\end{array}$ & $\begin{array}{c}159 \\
(57 \%)\end{array}$ & $\begin{array}{c}72 \\
(48 \%)\end{array}$ & $\begin{array}{c}132 \\
(50 \%)\end{array}$ & $\begin{array}{c}125 \\
(77 \%)\end{array}$ \\
\hline $\begin{array}{l}\text { Pile deviation towards } \\
\text { the pit (median), } \mathrm{cm}\end{array}$ & 20 & 18 & 19 & 25 \\
\hline $\begin{array}{l}\text { Pile deviation towards } \\
\text { the pit (maximum), } \\
\text { cm }\end{array}$ & $39-51$ & $37-49$ & $29-53$ & $50-79$ \\
\hline $\begin{array}{l}\text { Safety factor } \alpha \\
\text { (median value) }\end{array}$ & 17 & 21 & 22 & 34 \\
\hline $\begin{array}{c}\text { Deflection at accepted } \\
\alpha, \mathrm{cm}\end{array}$ & 19,7 & 17,0 & 17,5 & 23,3 \\
\hline $\begin{array}{l}\text { Maximum moment, } \\
\text { kNm }\end{array}$ & 32,7 & 80,5 & 78,1 & 87,7 \\
\hline
\end{tabular}




\section{References}

1. Mangushev R.A., Nikiforova N.S., Konyushkov V.V., Osokin A.I., Sapin D.A. Proektirovanie i ustrojstvo podzemnyh sooruzhenij v otkrytyh kotlovanah [Design and installation of underground structures in open pits]. Moscow, Saint-Petersburg, DIA Publishing House, 2013, 256 pages (in Russian).

2. GOST 27751-2014 Nadezhnost' stroitel'nyh konstrukcij i osnovanij. Osnovnye polozhenija [Reliability of building structures and foundations. The main provisions] (in Russian).

3. STO 38051320-001-2018 Sovremennye tehnologii pogruzhenija svaj vdavlivajushimi ustanovkami [Modern technologies for pile immersion with pressing units] (in Russian).

4. Ong D.E.L., Lung C.F., Chow J.K. Vlijanie predel'nogo davlenija na kust svaj prilegajushhij $\mathrm{k}$ obrushivshemusja otkosu kotlovana [The effect of ultimate pressure on the pile bush adjacent to the collapsed slope of the pit]. // Geotechnics, 2011, No. 6, pp. 52-59 (in Russian).

5. Paramonov V.N. Gorizontal'nye smeshhenija svaj pri razrabotke kotlovana [Horizontal displacements of piles during the development of the pit] // Geotechnics, 2018., Volume 10, No. 4, pp. 45-57 (in Russian).

6. Vershinin V.P., Gaido A.N., Sergeev Yu.O. O smeshhenie jelementov v svajnom fundamente pri otkopke kotlovana [On the displacement of elements in the pile foundation during excavation of the pit]. // Geotechnics, 2016, No. 1, pp. 32-39 (in Russian).

7. Mangushev R.A., Osokin A.I. Geotehnika Sankt-Peterburga [Geotechnics of St. Petersburg]. Moscow, ASV Publishing House, 2010, 264 pages (in Russian).

8. Mangushev R.A., Gotman A.L., Znamensky V.V., Ponomarev A.B. Svai i svajnye fundamenty. Konstrukcii, proektirovanie, i tehnologii [Piles and pile foundations. Constructions, design, and technology]. Moscow, ASV Publishing House, 2015, 320 pages (in Russian).

9. SP 45.13330.2017 Zemljanye sooruzhenija, osnovanija i fundamenty [Earthworks, footings and foundations] (in Russian).

10. Ilyichev V.A., Mangushev R.A. (Eds.) Spravochnik geotehnika. Osnovanija, fundamenty i podzemnye sooruzhenija [Reference geotechnics. Foundations, foundations and underground structures]. Moscow, ASV Publishing House, 2016, 1040 pages (in Russian).

11. Urban I.V. Raschet tonkih stenok s uchetom uprugih svojstv grunta i stenki [Calculation of thin walls, taking into account the elastic properties of the soil and walls]. // Transactions of MIIT, 1939, Issue. 55 (in Russian).

12. Zavriev K.S., Spyro G.S. Raschety fundamentov i mostovyh opor glubokogo zalozhenija [Calculations of foundations and bridge supports deep laying]. Moscow, Transport Publishing House, 1970, 216 pages (in Russian).

13. SNiP 2.02.03-85 Svajnye fundamenty [Pile foundations] (in Russian),

14. SP 24.13330.2011 Svajnye fundamenty [Pile foundations] (in Russian).

15. Lurie A.I. Teorija uprugosti [Theory of elasticity]. Moscow, Publishing House of Science, 1970, 940 pages.

16. Safonov A.P. Nesushhaja sposobnost' svaj v glinistyh gruntah pri dejstvii gorizontal'noj nagruzki [Bearing capacity of piles in clay soils under the action of horizontal load]. PhD Thesis. Sverdlovsk, 1984, 163 pages (in Russian).

17. Mangushev R.A., Ershov A.V., Ershov S.V. Ocenka vlijanija tehnologii izgotovlenija nabivnoj svai na sostojanie gruntovogo massiva [Evaluation of the impact of manufacturing technology of a printed pile on the state of the soil massif]. // Bulletin of civil engineers, 2009, No. 2, pp. 116-120 (in Russian). 


\section{СПИСОК ЛИТЕРАТУРЫ}

1. Мангушев P.A., Никифорова Н.С., Конюшков В.В., Осокин А.И., Сапин Д.А. Проектирование и устройство подземных сооружений в открытых котлованах. - М.: - СПб.: АСВ, 2013. $256 \mathrm{c}$.

2. ГОСТ 27751-2014 Надежность строительных конструкций и оснований. Основные положения.

3. СТО 38051320-001-2018 Современные технологии погружения свай вдавливающими установками.

4. Онг Д.Э.Л., Люнг Ч.Ф., Чоу Й.К. Влияние предельного давления на куст свай прилегающий к обрушившемуся откосу котлована. // Геотехника, 2011, №6, c.52-59.

5. Парамонов В.Н. Горизонтальные смещения свай при разработке котлована. // Геотехника, 2018, том 10, №4, с. 45-57.

6. Вершинин В.П., Гайдо А.Н., Сергеев Ю.О. О смещение элементов в свайном фундаменте при откопке котлована. // Геотехника, 2016, №1, с. 32-39.

7. Мангушев Р.А., Осокин А.И. Геотехника Санкт-Петербурга. - М.: ACB, 2010. - 264 c.

8. Мангушев Р.А., Готман А.Л., Знаменский В.В., Пономарев А.Б. Сваи и свайные фундаменты. Конструкции, проектирование, и технологии. - М.: ACB, 2015. - $320 \mathrm{c}$.

9. СП 45.13330.2017 Земляные сооружения, основания и фундаменты.

10. Ильичев В.А., Мангушев Р.А. (ред.) Справочник геотехника. Основания, фундаменты и подземные сооружения. M.: ACB, 2016. - 1040 c.

11. Урбан И.В. Расчет тонких стенок с учетом упругих свойств грунта и стенки. // Труды МИИТ, 1939, Выпуск 55.

12. Завриев К.С., Шпиро Г.С. Расчеты фундаментов и мостовых опор глубокого заложения. - М.: Транспорт, 1970. - 216 c.
13. СНиП 2.02.03-85 Свайные фундаменты.

14. СП 24.13330.2011 Свайные фундаменты.

15. Лурье А.И. Теория упругости. - М.: Наука, 1970. - 940 c.

16. Сафонов А.П. Несущая способность свай в глинистых грунтах при действии горизонтальной нагрузки. Диссертация на соискание ученой степени кандидата технических наук по специальности 05.23.02 - «Подземные сооружения, основания и фундаменты». - Свердловск: Уральский Ордена Трудового Красного Знамени политехнический институт им. С.М. Кирова, 1984. - 163 с.

17. Мангушев P.A., Ершов А.B., Ершов C.B. Оценка влияния технологии изготовления набивной сваи на состояние грунтового массива. // Вестник гражданских инженеров, 2009, №2, с. 116-120.

Rashid A. Mangushev, Corresponding Member of the Russian Academy of Architecture and Construction Sciences (RAACS), Professor, Dr.Sc.; Department of Geotechnics; Saint-Petersburg State University of Architecture and Civil Engineering; 5, Ulitsa Egorova, Saint-Petersburg, 190005, Russia;

phones: +7 (812) 316-03-41; 316-48-36

E-mail geotechnica@spbgasu.ru.

D.S. Kolesnik, Ph.D. Student; Department of Geotechnics; Saint-Petersburg State University of Architecture and Civil Engineering; 5, Ulitsa Egorova, Saint-Petersburg, 190005, Russia; phones: +7 (812) 316-03-41; 316-48-36

E-mail geotechnica@spbgasu.ru.

Мангушев Рашид Абдуллович, член-корреспондент РААСН, профессор, доктор технических наук; заведующий кафедрой геотехники; СанктПетербургский государственный архитектурностроительный университет; 190005, Россия, г. СанктПетербург, ул. Егорова 5;

тел. +7 (812) 316-03-41; 316-48-36

E-mail geotechnica@spbgasu.ru.

Колесник Д.С., аспирант кафедры геотехники; СанктПетербургский государственный архитектурностроительный университет; 190005, Россия, г. СанктПетербург, ул. Егорова 5;

тел. +7 (812) 316-03-41; 316-48-36

E-mail geotechnica@spbgasu.ru. 